\title{
Seasonal and Cross-Seasonal Timing of Fungicide Trunk Injections in Apple Trees to Optimize Management of Apple Scab
}

Srdan G. Aćimović, Michigan State University, Department of Plant, Soil and Microbial Sciences, East Lansing, MI 48824-1311; Anthony H. VanWoerkom, Trevor Nichols Research Center, Michigan State University, Fennville, MI; Thomas Garavaglia, Christine Vandervoort, and George W. Sundin, Michigan State University, Department of Plant, Soil and Microbial Sciences, East Lansing, MI 48824-1311; and John C. Wise, Michigan State University, Department of Entomology, East Lansing, MI 48824-1311

\begin{abstract}
Aćimović, S. G., VanWoerkom, A. H., Garavaglia, T., Vandervoort, C., Sundin, G. W., and Wise, J. C. 2016. Seasonal and cross-seasonal timing of fungicide trunk injections in apple trees to optimize management of apple scab. Plant Dis. 100:1606-1616.

To optimize the number and timing of trunk injections for season-long control of apple scab (Venturia inaequalis), we evaluated 1 to 2 and 4 seasonal and cross-seasonal injections of potassium phosphites and synthetic fungicides and quantified residues in leaves and fruit. Phosphites accumulated in the canopy at the highest concentrations, aligned well in time with scab suppression, and gave better leaf scab control of 41.8 to $73.5 \%$ than propiconazole (16.9 to $51.5 \%$ ) or cyprodinil + difenoconazole (5.4 to 17.4\%). More injections of phosphites controlled leaf scab better than fewer (23.7\% versus $48.2 \%$ ), and more fungicide injections resulted in 21.9 to $51.1 \%$ better leaf scab control than fewer. Leaf scab control with phosphites was only 3.2 to $13.9 \%$ better with 4 crossseasonal compared with 4 seasonal injections, while 1 to 2 seasonal compared with 1 to 2 cross-seasonal injections improved scab control only for

4.2 to $22.1 \%$. On shoots, injected phosphites provided comparable or for 4.4 to $10.5 \%$ and 22.3 to $41.4 \%$ better scab control than spray standards. On fruit, injected phosphites slightly improved control compared with sprayed phosphites or the sprayed fungicide standard (33.4 to $40.8 \%$ ). Two seasonal injections of phosphites controlled shoot scab 5.7\% better than 9 spray applications. Five sprays of cyprodinil + difenoconazole controlled scab better than their injections. Fruit residues of phosphites reached $2.8 \mathrm{ppm}$ and declined in all treatments except in 2 seasonal injections and phosphite sprays. Cyprodinil and difenoconazole fruit residues reached 0.02 and $0.07 \mathrm{ppm}$ and declined sharply toward the end of the season. These were far below the United States, Codex, and EU MRL-s of 1, 0.8 , and $0.5 \mathrm{ppm}$ for difenoconazole, and 1.7, 2, and $1 \mathrm{ppm}$ for cyprodinil, respectively.
\end{abstract}

The efficiency of plant disease management is strongly dependent on timing of pesticide applications. For maximum effect, spray treatments are aligned with pathogen life cycle and the susceptible growth stages of the plant. To control the devastating apple scab fungus Venturia inaequalis (Cooke) Wint., fungicides are applied before major infection periods associated by default to the calendar onset of apple tree growth stages, or applications are determined by weather-based predictive models for infection and monitoring of ascospore maturity and discharge (Gadoury et al. 2004; Stensvand et al. 2005). From the beginning of major ascospore release driven by wetness duration, fungicide sprays are typically repeated every 7 to 12 days or are delivered more closely before each of many ascospore discharge cycles. Repeated fungicide sprays are necessary to protect the intensively growing canopy and fruit from primary infections by ascospores. If left uncontrolled, apple scab infections occur, leading to formation of multiple generations of conidia that cause secondary infections resulting in higher costs of continued protection.

Once ascospore discharge ceases by depletion of pseudothecia, which in continental climate can occur from the end of May to the beginning of July, subsequent sprays are much farther apart or are ceased if the primary infections were well controlled (Smith et al. 1988; Stensvand et al. 2005). However, in many occasions, the ability to timely deliver protective sprays for efficient control is limited by prolonged rainy periods that prevent retention of fungicides on the canopy, or by unavailability of scab prediction information. This leads to unnecessary sprays that are not aligned with pathogen biology, thus lowering the efficiency of apple scab control and potentially

Corresponding author: Srđan G. Aćimović; E-mail: acimovic@msu.edu

Accepted for publication 11 February 2016.

http://dx.doi.org/10.1094/PDIS-09-15-1061-RE

(C) 2016 The American Phytopathological Society contributing to development of fungicide resistance in $V$. inaequalis. Pesticide overuse can also lead to excessive accumulation of residues in fruit, which increases health risks for consumers (FAO and WHO 2010; Hamilton et al. 2004; Rawn et al. 2007). Public concern over pesticide residues has put apple at the focus of scrutiny as one of the most heavily sprayed plants in agriculture (Sutton 1996).

Apple production in a humid climate can require up to 15 to 22 sprays of fungicides per season (Holb et al. 2005; Jamar et al. 2010). With each application, air-blast sprayers used in orchard tree protection deliver only 29 to $56 \%$ of pesticide solution into the canopy while the remaining amount is lost into the environment (Pimentel and Levitan 1986; Steiner 1969). Through off-target deposits and volatilization, pesticide losses contaminate soil, air, and water, endanger wildlife, and increase potential for human exposure (Ecobichon 1999; Pimentel 2005; Pimentel and Burgess 2014). It has also been shown that due to the negative environmental impacts of pesticide sprays, conventional apple production is less sustainable (Pimentel 2005; Reganold et al. 2001). In response to these problems, plant protection research in the past two decades focused on evaluating eco-friendly fungicides (Balaž et al. 2010; Jamar 2011), plant resistance activators (Aćimović et al. 2015b; Percival 2010; Percival et al. 2009), and full-scale utilization of the concept of integrated pest management (IPM) (Ehler 2006; Kogan 1998; Ohlendorf 1999). However, more sustainable apple production on a large scale is still not feasible. Reasons for this include the complexity of proposed methods (Creemers and Van Laer 2006), lack of highly efficient and eco-friendly protective products due to availability and/or fungicide resistance, and the lack of knowledge integration from different scientific disciplines that could support full IPM implementation (Beckerman et al. 2015; Ehler 2006; Ehler and Bottrell 2000; Epstein 2014; Jacobsen 1997).

To offset the need for frequent and timely biocide applications and to explore the possibility for reduced environmental exposure to pesticides, we investigated trunk injection as a target-precise alternative for pesticide delivery to apple trees (Aćimović et al. 2014, 2015b; VanWoerkom et al. 2014). In planta application of biocides 
could increase the sustainability of apple production through increased selectivity of pest exposure (Wise et al. 2014) and reduce pesticide use in the open environment (Zhang et al. 2011). Research in urban forestry and agriculture has shown that injected pesticides have longer persistency in insect and pathogen control, lasting for 2 to 3 seasons (Doccola et al. 2012; Smitley et al. 2010; VanWoerkom et al. 2014). Trunk injection of pesticides is currently the most accepted method for efficient and eco-friendly control of invasive insects and pathogens in landscape tree care
(Dal Maso et al. 2014; Mota-Sanchez et al. 2009). In apple scab control, injection could provide unprecedented benefit by replacing numerous sprays with fewer injections of fungicides per season (Düker and Kubiak 2011; Percival and Boyle 2005; Spitko 2008). However, designing efficient season-long control of apple scab by injected fungicides is still not feasible due to limited understanding of fungicide accumulation in the canopy and its timeline in relation to disease. Recent injection research indicated that fungicide doses and number of injections were not adjusted

Table 1. Trunk-injected compounds in one season and sprayed compounds for apple scab control on 'Red Delicious' apple trees

\begin{tabular}{|c|c|c|c|}
\hline \multicolumn{4}{|c|}{ Experiment 1} \\
\hline Treatment & Active ingredient & Dose & $\begin{array}{l}\text { Dates of injections or sprays in } \\
2012 \text { and of sprays in } 2013\end{array}$ \\
\hline Phosphojet low & Mono- and di-potassium salts of phosphorous & $2.59 \mathrm{ml} / 2.5 \mathrm{~cm}$ of $\mathrm{DFH}^{\mathrm{y}}$ & 21 March, 20 April, 25 May, 22 June \\
\hline Phosphojet high & $\begin{array}{l}\text { acid } 45.8 \% \text { (Phosphojet, Arborjet Inc., } \\
\text { Woburn, MA) }\end{array}$ & $5.17 \mathrm{ml} / 2.5 \mathrm{~cm}$ of DFH & 21 March, 20 April, 25 May, 22 June \\
\hline Prophyt & $\begin{array}{l}\text { Potassium phosphite 54.5\% (Prophyt, } \\
\text { Luxembourg-Pamol Inc., Memphis, TN) }\end{array}$ & $2.18 \mathrm{ml} / 2.5 \mathrm{~cm}$ of $\mathrm{DFH}$ & 21 March, 20 April, 25 May, 22 June \\
\hline Nutrol & $\begin{array}{l}\text { Potassium dihydrogen phosphate } 50 \% \\
\text { (Nutrol, LidoChem, Inc., Hazlet, NJ) }\end{array}$ & $3.56 \mathrm{~g} / 2.5 \mathrm{~cm}$ of DFH & 21 March, 20 April, 25 May, 22 June \\
\hline Alamo & $\begin{array}{l}\text { Propiconazole } 14.3 \% \text { (Alamo, Arborjet Inc., } \\
\text { Woburn, MA) }\end{array}$ & $12.5 \mathrm{ml} / 2.5 \mathrm{~cm}$ of $\mathrm{DFH}$ & 21 March, 20 April, 25 May, 22 June \\
\hline Water control & - & $30 \mathrm{ml} / 2.5 \mathrm{~cm}$ of DFH & 21 March, 20 April, 25 May, 22 June \\
\hline Spray standard & $\begin{array}{l}\text { Mancozeb 75\%, (Penncozeb } 75 \text { DF, } \\
\text { Cerexagri Inc., King of Prussia, PA) + } \\
\text { Fenarimol } 12 \% \text { (Rubigan EC, Dow } \\
\text { AgroSciences LLC, Indianapolis, IN) }\end{array}$ & $\begin{array}{l}2.7 \mathrm{~kg} / 0.405 \mathrm{ha}+354.9 \mathrm{ml} \\
/ 0.405 \mathrm{ha}\end{array}$ & $\begin{array}{l}22 \text { March; 3, 13, } 18^{\mathrm{z}} \text { April; and } 1 \text { May } 2012 \\
22 \text { April; } 1,8,16^{\mathrm{z}}, 21 \text { May; and } 4 \text { June } 2013\end{array}$ \\
\hline
\end{tabular}

Table 2. Trunk-injected compounds across two seasons and sprayed compounds for apple scab control on 'Mac Spur' apple trees

Experiment 2

\begin{tabular}{|c|c|c|c|c|c|}
\hline \multirow[b]{2}{*}{ Treatment } & \multirow[b]{2}{*}{ Active ingredient } & \multirow[b]{2}{*}{ Dose } & \multicolumn{3}{|c|}{ Dates of injections or sprays } \\
\hline & & & in 2011 & \multicolumn{2}{|c|}{ in 2012} \\
\hline Phosphojet low $\mathrm{F}^{\mathrm{v}}+3 \mathrm{~S}^{\mathrm{w}}$ & Mono- and di-potassium salts of phosphorous & $2.59 \mathrm{ml} / 2.5 \mathrm{~cm}^{\circ} \mathrm{DFH}^{\mathrm{x}}$ & 15 October & \multirow{2}{*}{\multicolumn{2}{|c|}{$\begin{array}{l}11 \text { April, } 11 \text { May, } 8 \text { June } \\
11 \text { April, } 11 \text { May, } 8 \text { June }\end{array}$}} \\
\hline Phosphojet high $\mathrm{F}+3 \mathrm{~S}$ & $\begin{array}{l}\text { acid } 45.8 \% \text { (Phosphojet, Arborjet Inc., } \\
\text { Woburn, MA) }\end{array}$ & $5.17 \mathrm{ml} / 2.5 \mathrm{~cm}$ of $\mathrm{DFH}$ & 15 October & & \\
\hline Alamo low $\mathrm{F}+3 \mathrm{~S}$ & Propiconazole $14.3 \%$ (Alamo, Arborjet Inc., & $8.3 \mathrm{ml} / 2.5 \mathrm{~cm}$ of DFH & 15 October & \multirow{2}{*}{\multicolumn{2}{|c|}{$\begin{array}{l}11 \text { April, } 11 \text { May, } 8 \text { June } \\
11 \text { April, } 11 \text { May, } 8 \text { June }\end{array}$}} \\
\hline Alamo high $\mathrm{F}+3 \mathrm{~S}$ & Woburn, MA) & $16.6 \mathrm{ml} / 2.5 \mathrm{~cm}$ of DFH & 15 October & & \\
\hline Water control & - & $8.3 \mathrm{ml} / 2.5 \mathrm{~cm}$ of DFH & 15 October & \multicolumn{2}{|c|}{11 April, 11 May, 8 June } \\
\hline Spray standard & $\begin{array}{l}\text { Mancozeb 75\%, (Penncozeb } 75 \text { DF, } \\
\text { Cerexagri Inc., King of Prussia, PA) + } \\
\text { Fenarimol 12\% (Rubigan EC, Dow } \\
\text { AgroSciences LLC, Indianapolis, IN) }\end{array}$ & $\begin{array}{l}2.7 \mathrm{~kg} / 0.405 \mathrm{ha}+354.9 \mathrm{ml} \\
/ 0.405 \mathrm{ha}\end{array}$ & & \multicolumn{2}{|c|}{$\begin{array}{l}27 \text { March; } 3,13,18^{y} \text { April; } \\
\text { and } 1 \text { May } 2012\end{array}$} \\
\hline \multicolumn{6}{|c|}{ Experiment 3} \\
\hline & & & \multicolumn{3}{|c|}{ Dates of injections or sprays } \\
\hline Treatments & Active ingredient & Dose & in 2012 & \multicolumn{2}{|c|}{ in 2013} \\
\hline Phosphojet F & Mono- and di-potassium salts of phosphorous & $5.17 \mathrm{ml} / 2.5 \mathrm{~cm}$ of DFH & 11 October & - & - \\
\hline Phosphojet F+ S $\mathrm{z}$ & acid $45.8 \%$ (Phosphojet, Arborjet Inc., & $5.17 \mathrm{ml} / 2.5 \mathrm{~cm}$ of DFH & 11 October & 21 April & - \\
\hline Phosphojet S & Woburn, MA; & $5.17 \mathrm{ml} / 2.5 \mathrm{~cm}$ of $\mathrm{DFH}$ & - & 21 April & - \\
\hline Phosphojet $\mathrm{S}+\mathrm{S}$ & & $5.17 \mathrm{ml} / 2.5 \mathrm{~cm}$ of $\mathrm{DFH}$ & - & 21 April & 22 May \\
\hline Agrifos sprays & $\begin{array}{l}\text { Agrifos, Agrichem PTY., Loganholme, QLD, } \\
\text { Australia) }\end{array}$ & $1,892.7 \mathrm{ml} / 0.405 \mathrm{ha}$ & \multicolumn{3}{|c|}{$\begin{array}{l}\text { 1, 8, 16, 21, } 31 \text { May and 5, 11, 19, } \\
26 \text { June } 2013\end{array}$} \\
\hline Inspire Super F & Cyprodinil $24.1 \%+$ difenoconazole $8.4 \%$ & $7 \mathrm{ml} /$ tree & 11 October & - & - \\
\hline Inspire Super S & (Inspire Super EW, Syngenta LLC, & $7 \mathrm{ml} /$ tree & - & 21 April & - \\
\hline Inspire Super $S+S$ & Greensboro, NC) & $7 \mathrm{ml} /$ tree & - & 21 April & 22 May \\
\hline Inspire Super sprays & & $354.8 \mathrm{ml} / 0.405 \mathrm{ha}$ & \multicolumn{3}{|c|}{$1,8,16,21,31$ May 2013} \\
\hline Water control & - & $500 \mathrm{ml} /$ tree & 11 October & 21 April & 22 May \\
\hline
\end{tabular}

${ }^{\mathrm{v}} \mathrm{F}$ - one fall injection.

w $3 S$ - three spring injections.

${ }^{x}$ DFH - trunk diameter at one foot height $(30.5 \mathrm{~cm})$.

y Date with single fenarimol application.

${ }^{\mathrm{z}} \mathrm{S}$ - one spring injection. 
to provide stable long-lasting apple scab control, which can avoid temporary side effects like phytotoxicity (Percival and Boyle 2005).

By monitoring disease and fungicide residue profiles in the canopy, the objective of the present study was to determine the optimal number and timing of compound injections needed to achieve one or two seasons of apple scab control. Seasonal timing of trunk injections and accumulation of pesticide residues are important parameters for optimizing pest management in other fruit trees such as avocado and date palms (Ahmed et al. 2010; Byrne et al. 2014). For injection, we chose eco-friendly potassium phosphites and synthetic anilinopyrimidine and triazole fungicides. We previously demonstrated that on mature apple trees, potassium phosphites induce broad-spectrum systemic acquired resistance and suppress fire blight (Erwinia amylovora), warranting further research for apple scab control (Aćimović et al. 2015b). On the other hand, synthetic fungicides are the most efficient compounds for apple scab control used in conventional apple production (Ehret et al. 2010).

To maximize the efficiency of injected compounds, we hypothesized that more injections would control apple scab better than fewer and that cross-seasonal injections in any form would control scab better than seasonal injections only. We hypothesized that peak

Table 3. The gradient mobile phase flow used for HPLC-MS residue analysis

\begin{tabular}{lcccc}
\hline Active ingredient & Time (min) & $\begin{array}{c}\text { Flow rate } \\
\left(\boldsymbol{\mu l} \mathbf{~ m i n}^{-\mathbf{1}}\right)\end{array}$ & $\begin{array}{c}\text { Solvent } \\
\mathbf{A}^{\mathbf{y}}(\boldsymbol{\%})\end{array}$ & $\begin{array}{c}\text { Solvent } \\
\mathbf{B}^{\mathbf{z}}(\boldsymbol{\%})\end{array}$ \\
\hline Phosphorous acid & & 0.30 & 90 & 10 \\
& 1.00 & 0.30 & 90 & 10 \\
& 9.00 & 0.30 & 10 & 90 \\
Cyprodinil & 9.10 & 0.30 & 90 & 10 \\
and difenoconazole & 5.00 & 0.30 & 75.0 & 25.0 \\
& 7.00 & 0.30 & 10.0 & 90.0 \\
& 7.50 & 0.30 & 10.0 & 90.0 \\
& 12.00 & 0.30 & 75.0 & 25.0 \\
& & & & \\
\hline
\end{tabular}

$\mathrm{y}$ Water with $0.1 \%$ formic acid.

${ }^{\mathrm{z}}$ Acetonitrile with $0.1 \%$ formic acid. compound residues accumulated in the apple canopy would align well with major infection periods for apple scab, especially when injected cross-seasonally. The goal was to use the residue data in fine-tuning of injection timing to optimize control of apple scab by injected compounds. In addition, we predicted that the effect of injected compounds on apple scab control would be comparable to the same compounds applied as foliar sprays or to the standard fungicide sprays.

\section{Materials and Methods}

Orchard experiments. Three experiments were conducted at the Michigan State University Trevor Nichols Research Center (TNRC) in Fennville, MI. In experiment 1, from half inch green apple phenological growth stage, we trunk-injected 14-year-old 'Red Delicious' apple trees four times in 2012 using compounds and doses shown in Table 1. In experiments 2 and 3, 29-year-old 'Mac Spur' apple trees were injected either four times across 2 years of 2011 and 2012 (cross-seasonal), or one to two times within a year (seasonal) or across 2 years (cross-seasonal) of 2012 and 2013, respectively (Table 2). In 2012 , injections were initiated at 50\% bloom and in 2013 at silver tip growth stages of apple. Injected doses were based on compound efficacy from previous research (VanWoerkom et al. 2014). In case of Prophyt (54.5\% potassium phosphite) and of Nutrol (potassium dihydrogen phosphate), doses were selected to match the active ingredient (a.i.) amount in the Phosphojet low treatment in Table 1.

In experiment 1 , all treatments except with Alamo (propiconazole) and Phosphojet were injected with $1,000 \mathrm{ml}$ of water to ease compound uptake and translocation into the crown. Propiconazole was amended with $30 \mathrm{ml}$ of water per each $2.5 \mathrm{~cm}$ of trunk diameter at $30.5 \mathrm{~cm}$ height ( $29.4 \%$ solution), also known as diameter at one foot height (DFH). Injected trees ranged from 14.0 to $19.1 \mathrm{~cm}$ in DFH, with an average of $16.7 \pm 0.3 \mathrm{~cm}$. We used completely randomized design (CRD) with four replicate trees per treatment. In experiment 2 , doses injected in 2011 were undiluted, while in 2012 only propiconazole was amended with $20 \mathrm{ml}$ of water per each $2.5 \mathrm{~cm}$ of DFH $(29.3$ and $45.4 \%$ solutions). Trees in experiment 2 ranged from 17.8 to $32.5 \mathrm{~cm}$ in DFH, with an average of $26.6 \pm 0.7 \mathrm{~cm}$. In experiment 3 , only Inspire Super (cyprodinil + difenoconazole) was injected with $500 \mathrm{ml}$ of water per tree (1.4\% solution). The dose of $7 \mathrm{ml}$ of

Table 4. Apple scab control on leaves with injected compounds on 'Red Delicious' trees ( $t$ tests, $\alpha=0.05)^{\mathrm{y}}$

\begin{tabular}{|c|c|c|c|c|c|c|}
\hline \multirow[b]{4}{*}{ Treatment } & \multicolumn{5}{|c|}{ Experiment 1} & \\
\hline & \multicolumn{6}{|c|}{ Mean apple leaf scab incidence in $2012(\%)$} \\
\hline & \multicolumn{2}{|c|}{ Spurs } & \multicolumn{4}{|c|}{ Shoots } \\
\hline & \multicolumn{2}{|c|}{ Mean for 4 and 18 May } & 4 May & 18 May & 14 June & 17 August \\
\hline Water control & \multicolumn{2}{|c|}{$81.9 \mathrm{~A}$} & $35.9 \mathrm{Ab}$ & $68.9 \mathrm{Aa}$ & $74.6 \mathrm{Aa}$ & $24.2 \mathrm{Ab}$ \\
\hline Phosphojet low & \multicolumn{2}{|c|}{$60.8 \mathrm{~B}$} & 21.7 Bbc & $32.4 \mathrm{Ba}$ & $24.2 \mathrm{Cab}$ & 13.0 CDc \\
\hline Nutrol & \multicolumn{2}{|c|}{$60.4 \mathrm{~B}$} & $16.8 \mathrm{Bb}$ & $32.8 \mathrm{Ba}$ & $45.9 \mathrm{ABa}$ & $16.8 \mathrm{BCb}$ \\
\hline Prophyt & \multicolumn{2}{|c|}{$53.5 \mathrm{~B}$} & $12.7 \mathrm{BCb}$ & $26.1 \mathrm{Ba}$ & $22.6 \mathrm{Ca}$ & $12.4 \mathrm{CDb}$ \\
\hline Phosphojet high & \multicolumn{2}{|c|}{$47.7 \mathrm{~B}$} & $16.3 \mathrm{BCbc}$ & $28.1 \mathrm{Ba}$ & $20.4 \mathrm{Cab}$ & $9.2 \mathrm{Dc}$ \\
\hline Alamo & \multicolumn{2}{|c|}{$-{ }^{z}$} & - & - & $30.0 \mathrm{BCa}$ & $15.1 \mathrm{BCb}$ \\
\hline \multirow[t]{3}{*}{ Spray standard } & \multicolumn{2}{|c|}{$16.7 \mathrm{C}$} & $9.5 \mathrm{Cc}$ & $14.1 \mathrm{Cb}$ & $28.2 \mathrm{BCa}$ & $30.8 \mathrm{Aa}$ \\
\hline & \multicolumn{6}{|c|}{ Mean apple leaf scab incidence in $2013(\%)$} \\
\hline & \multicolumn{2}{|c|}{ Spurs } & \multicolumn{4}{|c|}{ Shoots } \\
\hline Treatment & 13 June & 3 July & 13 June & 3 July & 30 July & 26 August \\
\hline Water control & $35.9 \mathrm{Ab}$ & $75.6 \mathrm{Aa}$ & $33.8 \mathrm{Ab}$ & 65.6 Aa & $71.9 \mathrm{Aa}$ & $80.0 \mathrm{Aa}$ \\
\hline Alamo & $34.1 \mathrm{Ab}$ & $58.6 \mathrm{Ba}$ & $25.2 \mathrm{ABc}$ & $53.0 \mathrm{ABb}$ & $47.1 \mathrm{Bb}$ & $77.9 \mathrm{Ba}$ \\
\hline Phosphojet low & $12.0 \mathrm{Ba}$ & $27.4 \mathrm{CDa}$ & $12.9 \mathrm{BCc}$ & $22.9 \mathrm{CDb}$ & $28.4 \mathrm{CDb}$ & $46.8 \mathrm{Ca}$ \\
\hline Prophyt & $11.6 \mathrm{Bb}$ & $31.7 \mathrm{Ca}$ & $14.3 \mathrm{BCb}$ & $41.0 \mathrm{BCa}$ & $36.0 \mathrm{BCa}$ & $44.5 \mathrm{CDa}$ \\
\hline Phosphojet high & $8.3 \mathrm{BCb}$ & $21.8 \mathrm{Ca}$ & $9.4 \mathrm{Cc}$ & $24.0 \mathrm{Db}$ & $20.0 \mathrm{Db}$ & $31.8 \mathrm{Da}$ \\
\hline Spray standard & $3.6 \mathrm{Ca}$ & $9.6 \mathrm{Da}$ & $2.8 \mathrm{Dd}$ & 13.1 Dc & $21.3 \mathrm{Db}$ & $37.9 \mathrm{CDa}$ \\
\hline
\end{tabular}

${ }^{y}$ Means within one date followed by different upper-case letters are significantly different. Means within one treatment across the two or four dates followed by different lower-case letters are significantly different.

${ }^{\mathrm{z}}$ Missing ratings due to phytotoxicity. 
cyprodinil + difenoconazole per tree was derived by dividing the maximum seasonal dose of this combination allowed by the EPA label in the United States, with 250 apple trees per acre (0.405 ha). In experiment 3, DFH ranged from 21.6 to $35.6 \mathrm{~cm}$ with an average of $28.0 \pm 0.5 \mathrm{~cm}$. Experiments 2 and 3 were arranged in CRD with six replicate trees per treatment.

Standard sprays were delivered with 189.3 liters of water per 0.405 ha, Agrifos sprays with 56.8 liters per 0.405 ha, and Inspire Super sprays with 94.6 liters per 0.405 ha. We applied the sprays in Tables 1 and 2 based on apple scab forecast reports for meteorological station located at TNRC (http://enviroweather.msu.edu).

Trunk injections. At each injection date (Table 1 and 2), a set of four cardinally-oriented trunk injection ports per tree were created perpendicularly by drilling $2.5 \mathrm{~cm}$ deep into the xylem tissue and $9.5 \mathrm{~mm}$ in diameter (Aćimović et al. 2014). The first set of ports was positioned approximately $25 \mathrm{~cm}$ above the ground level, while the subsequent sets were positioned $5 \mathrm{~cm}$ above and between the lower ports. Ports were sealed with Arborplug no. 4 (Arborjet Inc., Woburn, MA) as shown previously (Aćimović et al. 2015a).
In all experiments, drill-based injection systems with common drilling cavity dimensions were used so that performance of all treatments could be equally compared. We used the Quik-jet microinjection system (Arborjet Inc.) operating at hand-generated hydraulic pressure to deliver low volumes of liquid for injection, thus enabling faster application times, and the Tree IV air/hydraulic microinjection system (Arborjet Inc.) operating at up to $60 \mathrm{psi}$ of air pressure to deliver large volumes of liquid for injection $(\geq 600 \mathrm{ml})$. In experiment 1, we injected Phosphojet low and high treatments with Quik-jet (Table 1). We used Tree IV to inject all other treatments. In experiment 2, we injected all treatments in October 2011 with Quik-jet because the well-developed tree canopy allowed for good transpiration pull of sap in the xylem, thus easing the solution delivery uptake. In April 2012, we injected propiconazole with the Viper air/hydraulic microinjection system (Arborjet Inc.) at 90 psi of air pressure to compensate for weak sap flow (and hence poor solution delivery uptake) due to a weakly developed canopy. At all subsequent dates, we injected propiconazole with Tree IV and phosphites with Quikjet. In experiment 3, we injected phosphites with Quik-jet and cyprodinil + difenoconazole with Tree IV. We inserted injection

Table 5. Apple scab control with injected compounds on 'Mac Spur' apple trees $(t \text { tests, } \alpha=0.05)^{\mathrm{w}}$

\begin{tabular}{|c|c|c|c|c|c|}
\hline \multicolumn{6}{|c|}{ Experiment 2} \\
\hline \multirow[b]{3}{*}{ Treatment } & \multicolumn{5}{|c|}{ Mean apple leaf scab incidence in $2012(\%)$} \\
\hline & \multirow{2}{*}{$\frac{\text { Spurs }}{\text { Mean for } 1 \text { and } 16 \text { May }}$} & \multicolumn{4}{|c|}{ Shoots } \\
\hline & & 1 May & 16 May & 13 June & 15 August \\
\hline Water control $\mathrm{F}^{\mathrm{x}}+3 \mathrm{~S}^{\mathrm{y}}$ & $72.2 \mathrm{~A}$ & $20.3 \mathrm{Aa}$ & $50.5 \mathrm{Ab}$ & $72.8 \mathrm{Ac}$ & $72.5 \mathrm{Ac}$ \\
\hline Alamo low $\mathrm{F}+3 \mathrm{~S}$ & $59.8 \mathrm{~B}$ & $9.7 \mathrm{Ba}$ & $26.0 \mathrm{Bb}$ & 47.1 Bc & $38.6 \mathrm{Bc}$ \\
\hline Alamo high $F+3 S$ & $52.5 \mathrm{BC}$ & 5.4 CDa & $21.2 \mathrm{Bb}$ & $36.9 \mathrm{BCc}$ & $41.2 \mathrm{Bc}$ \\
\hline Phosphojet low $\mathrm{F}+3 \mathrm{~S}$ & $47.8 \mathrm{CD}$ & $9.5 \mathrm{BCa}$ & $12.4 \mathrm{Cac}$ & $29.0 \mathrm{CDb}$ & $15.9 \mathrm{Cc}$ \\
\hline Phosphojet high $\mathrm{F}+3 \mathrm{~S}$ & $39.3 \mathrm{D}$ & $7.5 \mathrm{BCa}$ & $7.3 \mathrm{Ca}$ & $24.9 \mathrm{Db}$ & $17.4 \mathrm{Cc}$ \\
\hline Spray standard & $15.5 \mathrm{E}$ & $3.9 \mathrm{Da}$ & $10.6 \mathrm{Cb}$ & $31.6 \mathrm{CDc}$ & $34.0 \mathrm{Bc}$ \\
\hline \multicolumn{6}{|c|}{ Experiment 3} \\
\hline & \multicolumn{5}{|c|}{ Mean apple scab incidence in $2013(\%)$} \\
\hline & Spurs & \multicolumn{4}{|c|}{ Shoots } \\
\hline Treatment / Season & $\overline{\text { Mean for } 17 \text { June and } 9 \text { July }}$ & 17 June & 9 July & 30 July & 30 August \\
\hline Water control & $88.3 \mathrm{~A}$ & $83.0 \mathrm{Ac}$ & $97.1 \mathrm{Ab}$ & $98.1 \mathrm{ABb}$ & $99.5 \mathrm{Aa}$ \\
\hline Inspire Super $S^{z}+S$ & $88.4 \mathrm{~A}$ & $75.3 \mathrm{ABb}$ & $80.7 \mathrm{Bb}$ & $88.1 \mathrm{BCa}$ & $92.6 \mathrm{ABa}$ \\
\hline Inspire Super S & $87.0 \mathrm{~A}$ & $69.0 \mathrm{Bb}$ & $75.6 \mathrm{Bb}$ & $83.0 \mathrm{Ca}$ & $84.4 \mathrm{BCa}$ \\
\hline Inspire Super F & $83.5 \mathrm{~A}$ & $83.0 \mathrm{Ac}$ & $95.5 \mathrm{Ab}$ & $98.7 \mathrm{Aa}$ & $98.9 \mathrm{Aa}$ \\
\hline Phosphojet F & $69.5 \mathrm{~B}$ & $56.6 \mathrm{Cb}$ & $73.7 \mathrm{BCa}$ & $71.7 \mathrm{Da}$ & $79.9 \mathrm{Ca}$ \\
\hline Phosphojet S & $65.8 \mathrm{~B}$ & 48.2 CDab & $44.5 \mathrm{~Eb}$ & $48.0 \mathrm{~Eb}$ & $58.2 \mathrm{Da}$ \\
\hline Agrifos sprays & $63.4 \mathrm{~B}$ & $45.4 \mathrm{Ea}$ & $29.6 \mathrm{Fb}$ & $34.0 \mathrm{Fab}$ & $38.8 \mathrm{Ea}$ \\
\hline Phosphojet $S+S$ & $52.1 \mathrm{C}$ & $36.0 \mathrm{EFa}$ & $32.3 \mathrm{Fa}$ & $23.2 \mathrm{~Gb}$ & $34.9 \mathrm{Ea}$ \\
\hline Phosphojet $\mathrm{F}+\mathrm{S}$ & $47.4 \mathrm{C}$ & $38.2 \mathrm{DFb}$ & $57.0 \mathrm{Da}$ & $38.7 \mathrm{EFb}$ & $55.4 \mathrm{Da}$ \\
\hline \multirow[t]{3}{*}{ Inspire Super sprays } & $36.3 \mathrm{D}$ & $27.5 \mathrm{Ed}$ & $66.4 \mathrm{CDc}$ & $91.7 \mathrm{ABCb}$ & 97.2 Aba \\
\hline & \multicolumn{5}{|c|}{ Fruit } \\
\hline & 17 June & 9 July & \multicolumn{2}{|r|}{30 July } & 30 August \\
\hline Inspire Super $S+S$ & $90.6 \mathrm{Abc}$ & $100.0 \mathrm{Aa}$ & \multicolumn{2}{|r|}{$96.7 \mathrm{Aac}$} & $100.0 \mathrm{Aab}$ \\
\hline Inspire Super F & $89.0 \mathrm{Aa}$ & $98.2 \mathrm{Aa}$ & \multicolumn{2}{|r|}{$97.9 \mathrm{Aa}$} & $99.5 \mathrm{Aa}$ \\
\hline Inspire Super S & 87.3 Aa & $87.5 \mathrm{Aa}$ & \multicolumn{2}{|r|}{$83.3 \mathrm{ABa}$} & $100.0 \mathrm{Aa}$ \\
\hline Water control & $84.6 \mathrm{Ab}$ & $98.0 \mathrm{Aa}$ & \multicolumn{2}{|r|}{$99.2 \mathrm{Aa}$} & $100.0 \mathrm{Aa}$ \\
\hline Agrifos sprays & $60.5 \mathrm{Ba}$ & $60.1 \mathrm{BCa}$ & \multicolumn{2}{|r|}{$72.5 \mathrm{Ba}$} & $78.6 \mathrm{BCa}$ \\
\hline Phosphojet F & $53.6 \mathrm{BCc}$ & $77.0 \mathrm{Bb}$ & \multicolumn{2}{|r|}{$93.4 \mathrm{ABa}$} & $87.5 \mathrm{ABa}$ \\
\hline Inspire Super sprays & $36.1 \mathrm{Cc}$ & $62.0 \mathrm{BCDb}$ & \multicolumn{2}{|r|}{$82.5 \mathrm{Ba}$} & $89.2 \mathrm{ABa}$ \\
\hline Phosphojet $\mathrm{S}+\mathrm{S}$ & $28.9 \mathrm{BCa}$ & $22.9 \mathrm{DEa}$ & \multicolumn{2}{|r|}{$30.6 \mathrm{Ca}$} & $33.3 \mathrm{Da}$ \\
\hline Phosphojet S & $27.4 \mathrm{Cb}$ & $26.7 \mathrm{CEb}$ & \multicolumn{2}{|r|}{$29.6 \mathrm{Cb}$} & $58.5 \mathrm{CDa}$ \\
\hline Phosphojet F + S & $17.2 \mathrm{Cb}$ & $25.7 \mathrm{~Eb}$ & \multicolumn{2}{|r|}{$47.1 \mathrm{Ca}$} & 45.3 Dab \\
\hline
\end{tabular}


needle(s) of each of the aforementioned devices through the Arborplugs (Aćimović et al. 2015a) and the total solution volume per tree, at one injection time, was divided and delivered equally among the four ports.

Evaluation of apple scab. In experiment 1, apple scab was rated only on leaves and throughout 2012 and 2013. In experiment 2, apple scab was rated in 2012 and only on leaves, since fruits were lost due to spring frosts. In experiment 1, fruits did not set again in 2013 for unknown reasons. In experiment 3 , we rated scab on both leaves and fruit in 2013. We chose 20 spurs and 20 terminal shoots per tree replicate, with about five from each crown quadrant, and rated leaf scab incidence using a previously reported method (Ehret et al. 2010). Fruit scab incidence was rated by examining 100 fruits per tree, with about 25 per crown quadrant, and if less was found we rated all fruits on a tree.

We analyzed apple scab control with mixed models using MIXED procedure in SAS 9.3 (SAS Institute, Cary, NC). For experiment 1, spur and shoot scab incidences in 2012 were square root and log transformed and analyzed with repeated measures best adjusted using unstructured and spatial power covariance structures, respectively. In 2013, spur scab incidences were not transformed and shoot scab incidences were $\log$ transformed. Control of both was analyzed with repeated measures best adjusted using unstructured and heterogeneous compound symmetry covariance structures, respectively. For experiment 2, incidences of spur and shoot leaf scab were cosine and square root transformed and analyzed with repeated measures best adjusted using heterogeneous autoregressive and a spatial power covariance structures, respectively. For experiment 3, spur scab incidences were arcsine transformed and analyzed using time as a fixed factor. Fruit scab incidences were cosine transformed and shoot scab data were not transformed. Control of both was analyzed with repeated measures best adjusted using spatial power covariance structure. In the analyses, tree was the subject of repeated measures. When the main effects or their interactions were statistically significant in repeated measures $(P<0.05)$, examination, i.e., slicing of interactions within main effects, was performed, $F$-tests were conducted, and pairwise or specific time or treatment comparisons were done using $t$ tests $(\alpha=0.05)$.

Fungicide residue analysis in experiments 2 and 3. In experiment 2, we collected only leaf samples and in experiment 3 , bud, leaf, and fruit samples. We took one composite sample of 40 uniformly chosen leaves or buds per tree crown (10 leaves per cardinal direction). Leaf samples in experiment 2 were taken at $0,14,28,42,56$, 70 , and 84 days after first injection in 2012 (DAFI). Bud and leaf samples in experiment 3 were taken 14 DAFI in fall 2012 and then at $0,10,24,38,52,66$, and 80 days after the second injection (DASI) in 2013. In experiment 3, depending on the fruit size, during 2013 we collected one composite fruit sample per tree consisting of 20 uniformly picked fruits across the tree crown in the spring or four in the summer (five or one fruit per each cardinal direction). The average fruit sample weights, after collection at 40, 58, 80, and 133 DASI, were $16.7,55.6,69.8$, and $77.1 \mathrm{~g}$, respectively. We stored residue samples for synthetic fungicides at $5^{\circ} \mathrm{C}$, in $20,40,60,75$, or $90 \mathrm{ml}$ of HPLC-grade dichloromethane (DCM, EMD Chemicals Inc., Gibbstown, NJ), depending on the sample size. To determine fungicide residues in all samples, we conducted the extraction using previously reported protocol (Aćimović et al. 2014). The residue samples for potassium phosphites were stored at $-20^{\circ} \mathrm{C}$ until the extraction, conducted by using a previously reported method (Malusà and Tosi 2005; VanWoerkom et al. 2014).

Samples were analyzed for propiconazole (parent compound) with Agilent Technologies 7890A GC system/MSD-5973 Mass Selective Detector Network with Agilent HP-5MS 5\% phenyl methyl silox column $(30 \mathrm{~m} \times 250 \mu \mathrm{m} \times 0.25 \mu \mathrm{m}$, Agilent Technologies Inc., Santa Clara, CA). We monitored the same propiconazole ions as reported before (VanWoerkom et al. 2014). The quantification level for propiconazole was $0.05 \mathrm{mg} \mathrm{kg}^{-1}$ of a.i. and level of detection was $0.165 \mathrm{mg} \mathrm{kg}^{-1}$. Samples were analyzed for difenoconazole, cyprodinil, and phosphorous acid residues with the same HPLC-MS equipment reported previously for trunk-injected fungicides (VanWoerkom et al. 2014). We used the same mobile phase solvent A (water with $0.1 \%$ formic acid) and solvent B (acetonitrile with $0.1 \%$ formic acid) as in this study, and for cyprodinil and difenoconazole, these were initially held at $75 \%$ solvent A and $25 \%$ solvent B and followed by a gradient shown in Table 3. For phosphorus acid, these were initially kept at $90 \%$ solvent $\mathrm{A}$ and $10 \%$ solvent B, followed by a gradient shown in Table 3 . For difenoconazole, we monitored ions 250.87 and $405.96 \mathrm{~m} / \mathrm{z}$ (Da) and for cyprodinil 93.14, 118.51, and $226.18 \mathrm{~m} / z$ (Da). Monitored ions for phosphorous
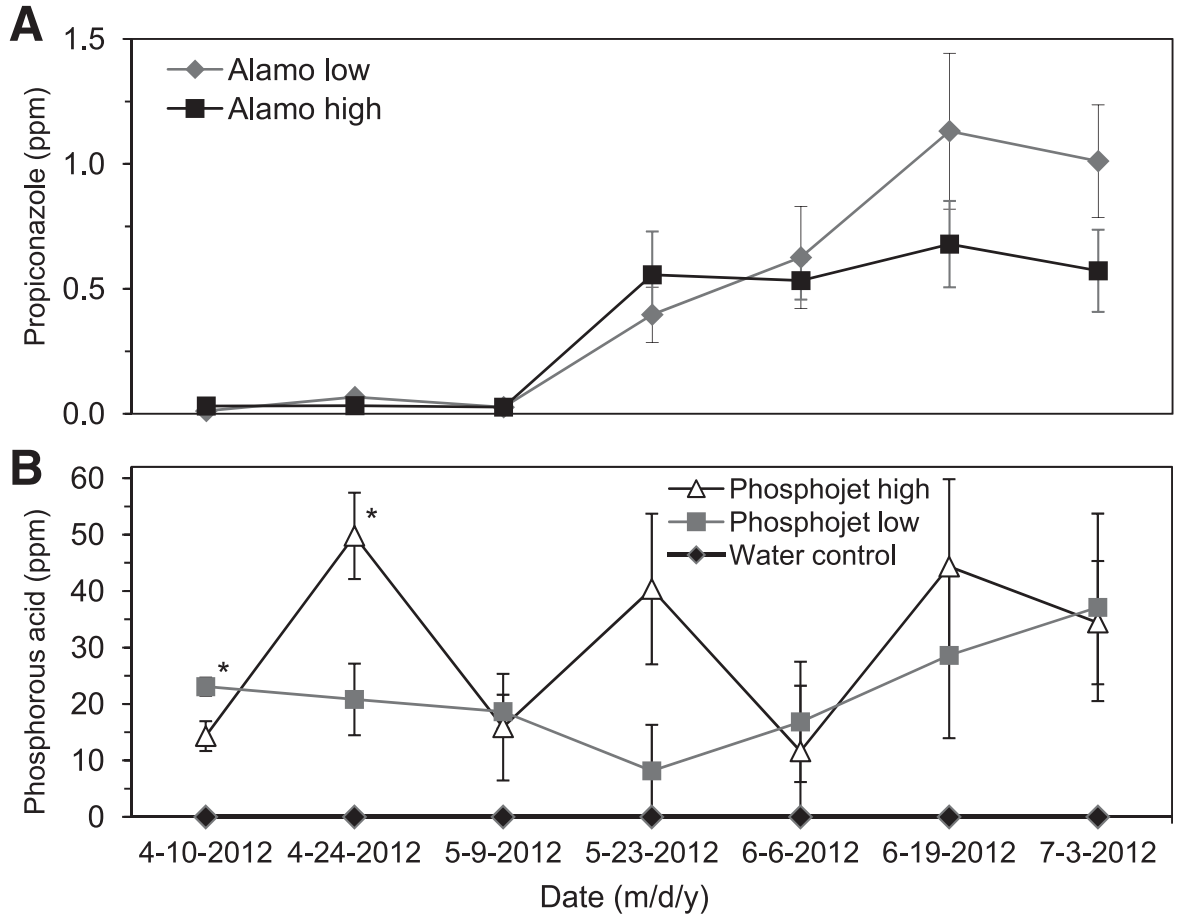

Fig. 1. Leaf residue profiles of trunk-injected propiconazole (Alamo) (A) and potassium phosphites (Phosphojet) (B) expressed as phosphorous acid in 'Mac Spur' apples for experiment 2. Means within one date followed by an asterisk are significantly different ( $t$ tests, $\alpha=0.05)$. Error bars represent standard error of the mean (SEM). 
acid were $38.5,38.96,80.07$, and $80.7 \mathrm{~m} / \mathrm{z}$ (Da). The quantification level for phosphorus was $0.005 \mathrm{mg} \mathrm{kg}^{-1}$ and the level of detection was $0.0165 \mathrm{mg} \mathrm{kg}^{-1}$. The quantification levels for difenoconazole and cyprodinil were 0.00510 and $0.0505 \mathrm{mg} \mathrm{kg}^{-1}$ and the levels of detection were 0.01683 and $0.16665 \mathrm{mg} \mathrm{kg}^{-1}$, respectively.

We analyzed residues with mixed models using MIXED procedure in SAS 9.3. For experiment 2, quantified residues of propiconazole and phosphorous acid in leaves were square root and arcsine transformed, respectively. We analyzed the residues of these a.i.s with repeated measures best adjusted using unstructured and heterogeneous autoregressive covariance structures, respectively. For experiment 3, cyprodinil and difenoconazole residues in leaves were $\log 10$ and square root transformed, respectively. We analyzed cyprodinil residues with repeated measures best adjusted using a heterogeneous compound symmetry covariance structure, considering time as a fixed factor. We analyzed difenoconazole residues with repeated measures best adjusted using unstructured covariance structure. Fruit residues of cyprodinil and difenoconazole were both log 10 transformed. We analyzed fruit residues of cyprodinil with repeated measures best adjusted using unstructured covariance structure and of difenoconazole with time as a fixed factor. Phosphorous acid residues in leaves and fruits were $\log 10$ and sine transformed, respectively. We analyzed these leaf and fruit residues with repeated measures best adjusted using unstructured and a heterogeneous autoregressive covariance structures, respectively. Tree was the subject of repeated measures. When the main effects or their interactions in repeated measures were statistically significant $(P<0.05)$, examination, i.e., slicing of interactions within main effects, was performed, $F$-tests were conducted, and pairwise or specific time or treatment comparisons were conducted using $t$ tests $(\alpha=0.05)$.

\section{Results}

Apple scab control. In experiment 1, all injected compounds except potassium dihydrogen phosphate in 2013, reduced leaf apple scab for two consecutive seasons (Table 4). In 2013, propiconazole failed to provide continuous control while potassium dihydrogen phosphate was not rated (Table 4). Leaf scab control on shoots (44.8 to $63.8 \%$ ) was better in 2012 than on spurs (25.8 to $41.8 \%$ ) while in 2013 it was better on spurs (16.8 to 72.9\%) compared with shoots $(19.1$ to $66.1 \%)$. On shoots, the effects were statistically similar or better at the end dates of 2012 and 2013 when compared with the spray standard (Table 4). In the water control, infected basal leaves defoliated from shoots. After injection, propiconazole caused phytotoxicity as scorching of unfolding leaves and prevented rating until refoliation (Table 4).

In experiment 2 , injected compounds significantly reduced the incidence of leaf apple scab and provided largely comparable or 6.1 to $10.5 \%$ better control of shoot scab than the spray standard (Table 5). On average, phosphites provided better control of spur scab than propiconazole (33.8 and $45 \%$ versus 17.2 and $27.3 \%$ ) as well as of shoot scab $(69.1$ and $73.5 \%$ versus $43.7 \%$ and $51.5 \%)$. In experiment 3 , significant reduction of leaf and fruit scab showed that double and single phosphite injections outperformed or largely mirrored the phosphite sprays in control of spur scab: 41 and $46.3 \%$ versus
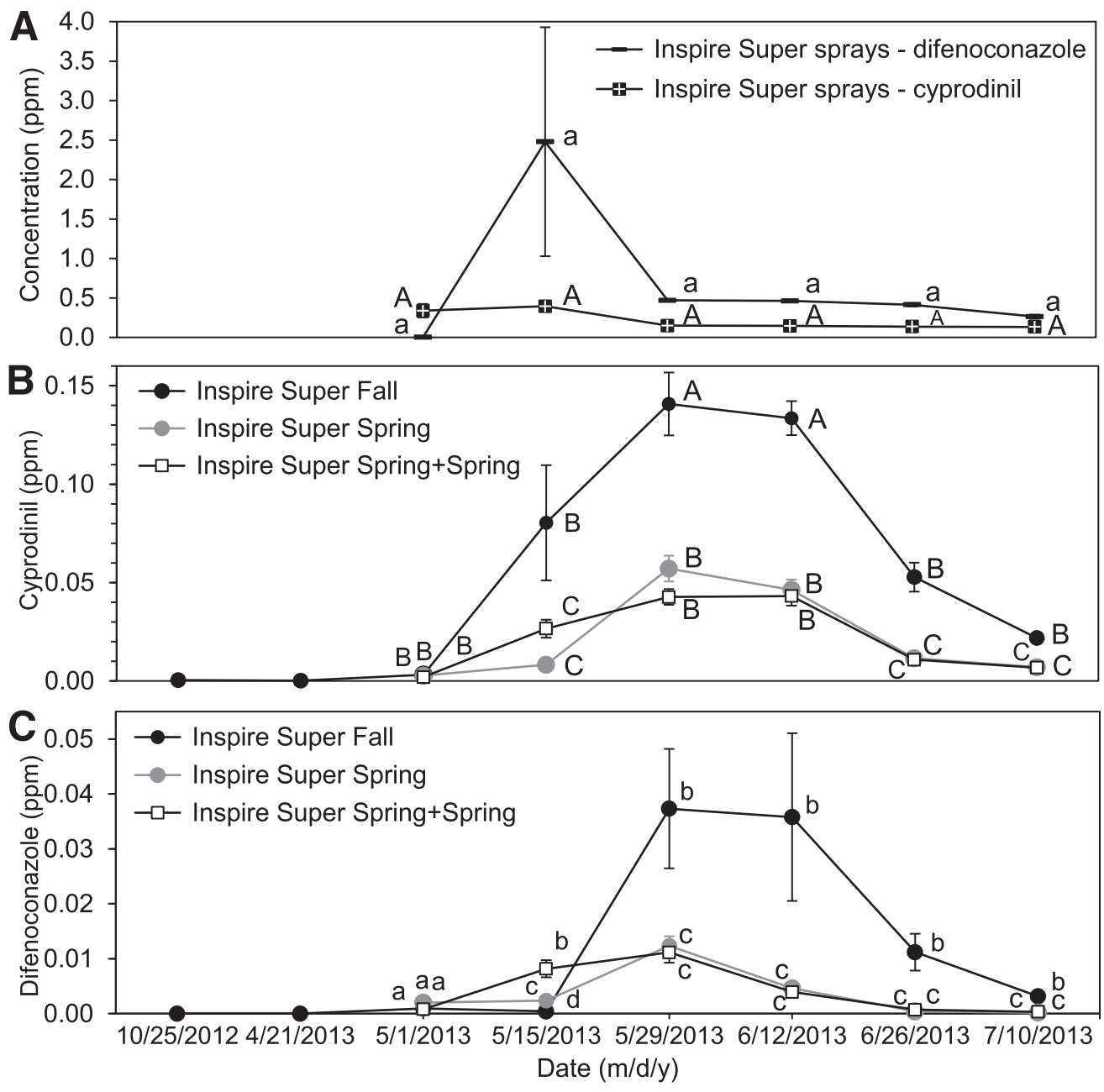

Fig. 2. Leaf residue profiles of cyprodinil and difenoconazole (Inspire Super) after sprays (A) and after trunk-injection (B, C) in 'Mac Spur' apple trees for experiment 3. Fall/Spring injection season. Means of one compound within one date followed by different lower- or upper-case letters are significantly different between the treatments and across the graphs ( $t$ tests, $\alpha=0.05$ ). Error bars represent standard error of the mean (SEM). 
$28.2 \%, 21.3$ and $25.5 \%$ versus $28.2 \%$, respectively (Table 5). On shoots, only double spring phosphite injection outperformed phosphite sprays in control (66.5\% versus $60.8 \%$ ), while on fruit, both double phosphite injections and a single spring injection outperformed phosphite sprays: $64.6,69.7$, and $62.7 \%$ versus $28.9 \%$, respectively. Double phosphite injections provided better scab control than the single injections (spurs: 41 and $46.3 \%$ versus 21.3 and $25.5 \%$; shoots: 49.9 and $66.5 \%$ versus 25.3 and $47.4 \%$; fruit: 64.6 and $69.7 \%$ versus 18.4 and $62.7 \%$ ). Primarily early in the season, cyprodinil + difenoconazole sprays outperformed this combination's injections in control of both leaf and fruit scab (spurs: 58.9 versus $-0.11,1.5$, and 5.4\%; shoots: 25.1 versus $0.4,10.8$, and $17.4 \%$; fruit: 29.3 versus $-1.4,-0.7$, and $6.3 \%$ ). Among injection treatments, phosphites gave the best leaf and fruit scab control, outperforming cyprodinil + difenoconazole.

Fungicide residue profiles. Over time, trunk injections in experiment 2 allowed increasing accumulation of propiconazole in leaves and a variable accumulation of phosphites (Fig. 1). Propiconazole injection treatments did not differ in residue profiles, while phosphites treatments differed only in April 2012. Phosphites accumulated in leaves at a much higher level in comparison with propiconazole (Fig. 1).

In experiment 3, injection treatments and time significantly affected compound residue levels in apple leaves and fruit (Figs. 2 to 5). For clarity, differences between residue means across time points within each treatment are not shown (Figs. 2 to 5). Injected cyprodinil and difenoconazole accumulated more in leaves than in apple fruit. In apple buds and leaves, residues of injected cyprodinil and difenoconazole compared with the sprayed were 10- to 100-fold lower (Fig. 2A to $\mathrm{C}$ ). The leaf residues of cyprodinil and difenoconazole increased and declined more gradually after injection than after sprays. Injected cyprodinil accumulated in leaves at a 10-fold higher concentration than difenoconazole (Fig. 2B and C). Fall injection allowed higher cyprodinil and difenoconazole residue accumulation in comparison with single or double spring injections (Fig. 2B and C). Cyprodinil and difenoconazole residues in apple fruit were 10-fold lower after injection when compared with sprays and declined more sharply after sprays and fall injection versus the spring injections (Fig. 3A to C). Injected cyprodinil accumulated in fruits at a 10-fold higher concentration than difenoconazole (Fig. 3B and C). Only fall versus spring injection gave higher cyprodinil accumulation in May 2013 (Fig. 3B). In experiment 3, phosphite residues in leaves and fruit were higher than cyprodinil and difenoconazole residues (Figs. 2 to 5). Accumulation of phosphites in leaves was slower compared with cyprodinil and difenoconazole (Figs. 2 and 4). When compared within one plant organ, injections provided largely similar phosphite residue profiles (Figs. 4 and 5). Phosphite injections gave similar or higher residue profiles in leaves compared with phosphite sprays (Fig. 4). Fall injection gave temporarily higher phosphite accumulation in leaves compared with spring phosphite injections and sprays. Phosphites accumulated slower in apple fruit and peaked a month later than in the leaves. Phosphite residues in fruit were largely similar between the injections and sprays.
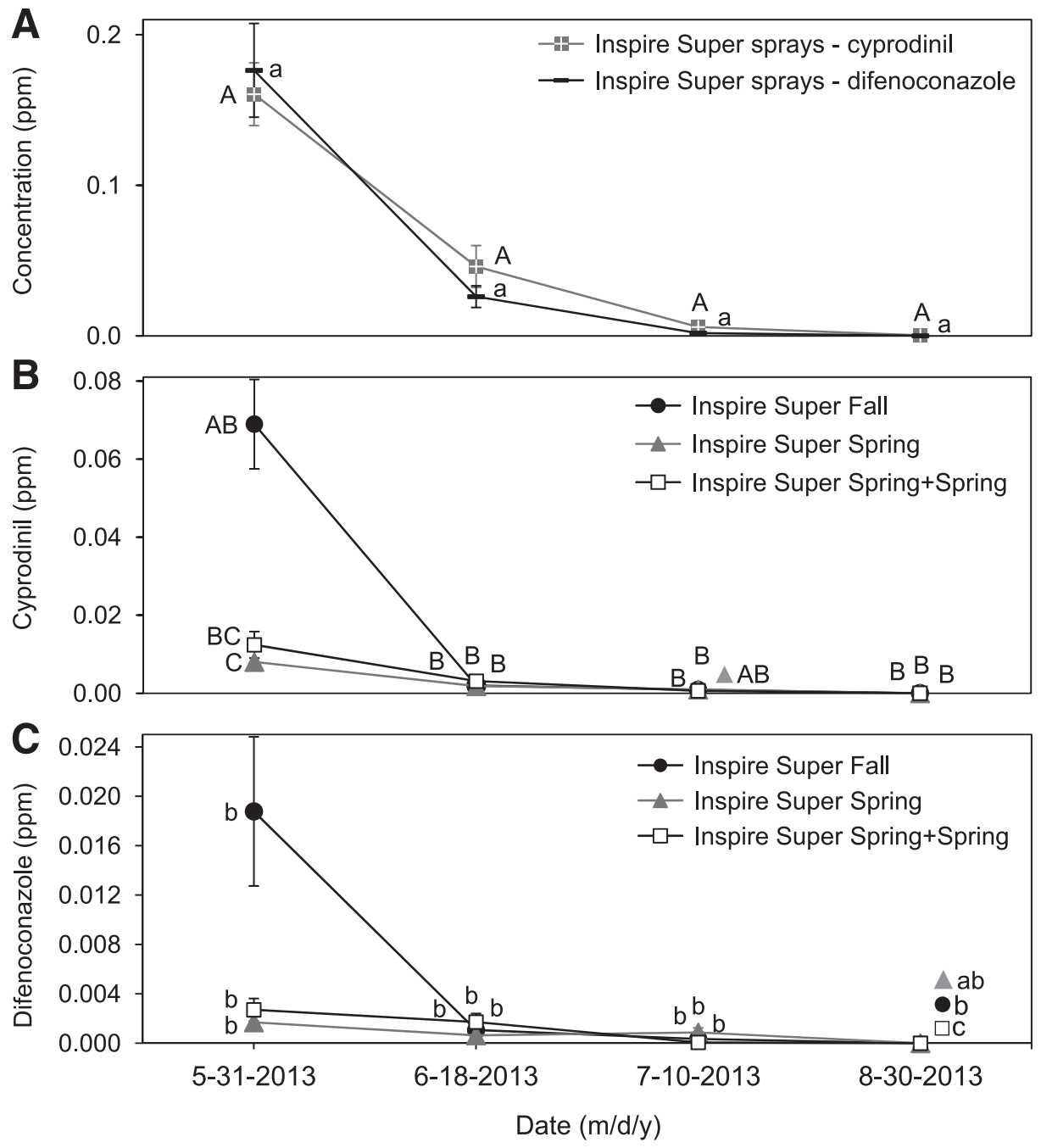

Fig. 3. Fruit residue profiles of cyprodinil and difenoconazole (Inspire Super) after sprays (A) and after trunk-injection (B, C) in 'Mac Spur' apple trees for experiment 3. Fall/Spring injection season. Means of one compound within one date followed by different lower- or upper-case letters are significantly different between the treatments and across the graphs ( $t$ tests, $\alpha=0.05$ ). Error bars represent standard error of the mean (SEM). 


\section{Discussion}

We provide new insight on the efficiency of apple scab control with differentially timed injections of compounds with accompanying data on the accumulation of leaf and fruit residues in the canopy. This could facilitate the improvement of precise apple scab management by in planta compound delivery with minimal environmental exposure. Four injections of phosphites resulted in the most successful scab control, which in case of spring injections only, extended into the second season without additional injections. These injections in one season yielded largely comparable control to two seasons of standard sprays. The level of scab control varied depending on the injected compound and the organ in the canopy. Fall injection of phosphites, followed by three injections in the spring, improved apple scab control on leaves in the coming season. However, when a fall phosphite injection was followed by only one additional injection in spring, control did not improve on leaves or fruit.

The leaf and fruit residues of phosphites aligned better with scab control compared with the other fungicides. Specific residue profiles in buds, leaves, and fruit, along with variable effects on apple scab, point to differential influence of tree and organ-specific physiology, compound properties, and injection timing on accumulation of compounds in the canopy. Due to the occurrence of major water transport in xylem, at least one to two early spring injections can give good disease control, depending on canopy organ. Compound accumulation and apple scab control varied depending on the transpiration footprint of the organ and the number of injections determining the dose per tree. The results imply that quantities of accumulated residues and thus activity of injected compound in the canopy depend on its mobility in xylem, an environment rich in organic compounds. In the case of phosphites, which are readily mobile in xylem, higher residue accumulation and better or comparable apple scab control can be achieved with fewer injections than sprays per year.

Injected phosphites provided the best apple scab control, indicating their favorable chemical properties for good translocation and abundant accumulation in the canopy. Phosphites suppress $V$. inaequalis and can control other apple pathogens such as Phytophthora cactorum and P. cambivora (Heaton and Dullahide 1990). When injected, phosphites induced systemic acquired resistance (SAR) in mature apple trees allowing control of fire blight caused by the bacterial pathogen Erwinia amylovora (Aćimović et al. 2015b). Besides plant defense responses, phosphites also directly affect several oomycete plant pathogens (Deliopoulos et al. 2010; Smillie et al. 1989; Walters and Bingham 2007). Apple scab control with injected phosphites and then the other fungicides was the best on shoot leaves followed by apple fruit, and lastly on spur leaves. This implies that injected compounds accumulate more in shoot leaves than in spur leaves and that they accumulate more in fruit than in spur leaves. This is probably driven by variable rates of transpiration from these organs, governing the speed and abundance of compound accumulation after injection. The total leaf area of spurs is smaller in comparison with shoots. Spurs have limited numbers of leaves, which are first to develop in the season and reach their full size early in the spring. In contrast, shoot leaves are repeatedly formed from petal fall to terminal bud set on actively-growing shoots. With more stomata on more numerous shoot leaves, transpiration intensity increases,
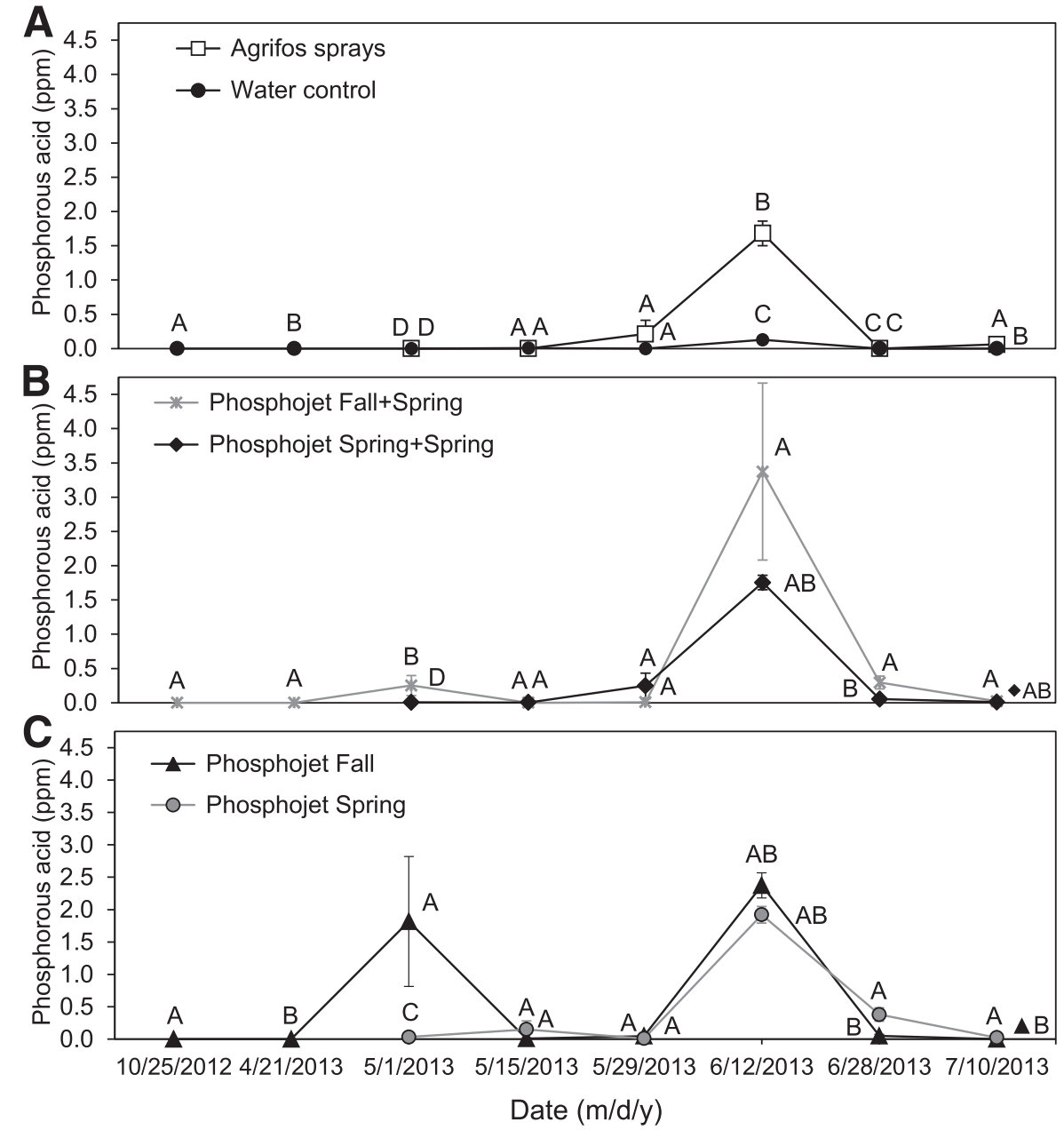

Fig. 4. Leaf residue profiles of trunk-injected and sprayed potassium phosphites (Agrifos or Phosphojet) in 'Mac Spur' apples. A, Agrifos sprays and water control. B, Double injections and C, single injections of Phosphojet. Fall/Spring - injection time. Residue means within one date followed by different letters are significantly different between the treatments and across the graphs ( $t$ tests, $\alpha=0.05$ ). Error bars represent standard error of the mean (SEM). 
driving the abundant accumulation of injected compound and thus better scab control. For example, apple fruits have 10- to 100-fold lower frequency of stomata on their epidermis in comparison with leaves (Blanke and Lenz 1989). This could explain why apple scab control was lower on fruit than on shoots.

Fall injection of phosphites or propiconazole followed by an additional three injections in spring improved control of leaf scab early in the season. However, this improvement by fall injection was not detected for phosphites and cyprodinil + difenoconazole when followed by one additional spring injection, since a single or double spring injections of these compounds provided comparable or better scab control on leaves and fruit. Improved apple scab control with four cross-seasonal injections worked in concert with the higher dose delivered per tree. In the case of two cross-seasonal injections, the dose per tree was lower. This implies that when fewer injections are used, control of scab is better if the compound is delivered in spring, when water transport in xylem is most intensive. Transpiration in apple trees gradually declines toward the end of the season (Dragoni et al. 2005). Hence, contribution of fall injection of a compound to scab control in the next season is compromised by weak transpiration, preventing higher compound accumulation in the canopy, and by a large time separation form the next injection in spring. Bearing in mind variable transpiration footprints of different organs in the canopy, these results imply that optimal control of apple scab could be achieved with two to three injections of fungicides delivered in spring or with one fall injection followed by two spring injections.

Due to four injections in experiment 2 , considerably more phosphite residues accumulated in leaves than in experiment 3 . Since phosphites have high water solubility of 500 g/liter and a low organic carbon-water partitioning coefficient (Koc) of 228 to $587 \mathrm{ml} / \mathrm{g}$ (EFSA 2012), which depicts the level of compound adsorption to carbon compounds, they accumulated more in leaves and fruit than the other fungicides. This suggests good systemic properties, i.e., vertical movement of phosphites in the tree xylem. Propiconazole, cyprodinil, and difenoconazole have low to very low water solubilities of 100 to $150 \mathrm{mg} / \mathrm{liter}, 15 \mathrm{mg} / \mathrm{liter}$, and $13 \mathrm{mg} / \mathrm{liter}$, respectively (Herner and Acock 2003; Mensink 2008; Serafini 2003). Their Kocs are moderate to high with 1,086 to $1,817 \mathrm{ml} / \mathrm{g}, 1,550$ to $2,030 \mathrm{ml} / \mathrm{g}$, and 3,870 to $11,202 \mathrm{ml} / \mathrm{g}$, respectively (PPDB 2013; Serafini 2003; Tomlin 2011). These properties account for medium low to very low mobility in xylem as tissue rich in carbon compounds and explain low residue profiles that we detected in apple canopy. Accordingly, cyprodinil is a systemic while difenoconazole is a local systemic fungicide. Compounds with these properties strongly bind to the organic phase of xylem symplast and apoplast (Doccola et al. 2012). This is known as reservoir effect and Koc is important parameter for explaining limited accumulation of injected compounds in the canopy (Doccola et al. 2012; Tanis et al. 2012). High Koc of propiconazole supports the lack of difference between accumulation residue profiles of two different doses injected in experiment 2 and their effect on apple scab. Besides Koc and water solubility, it is possible that inert components of the foliar formulation we injected hampered abundant accumulation of cyprodinil and difenoconazole and better scab control in the canopy. Pesticides have to be specifically formulated for injection, in order to move well through xylem, and often diluted before
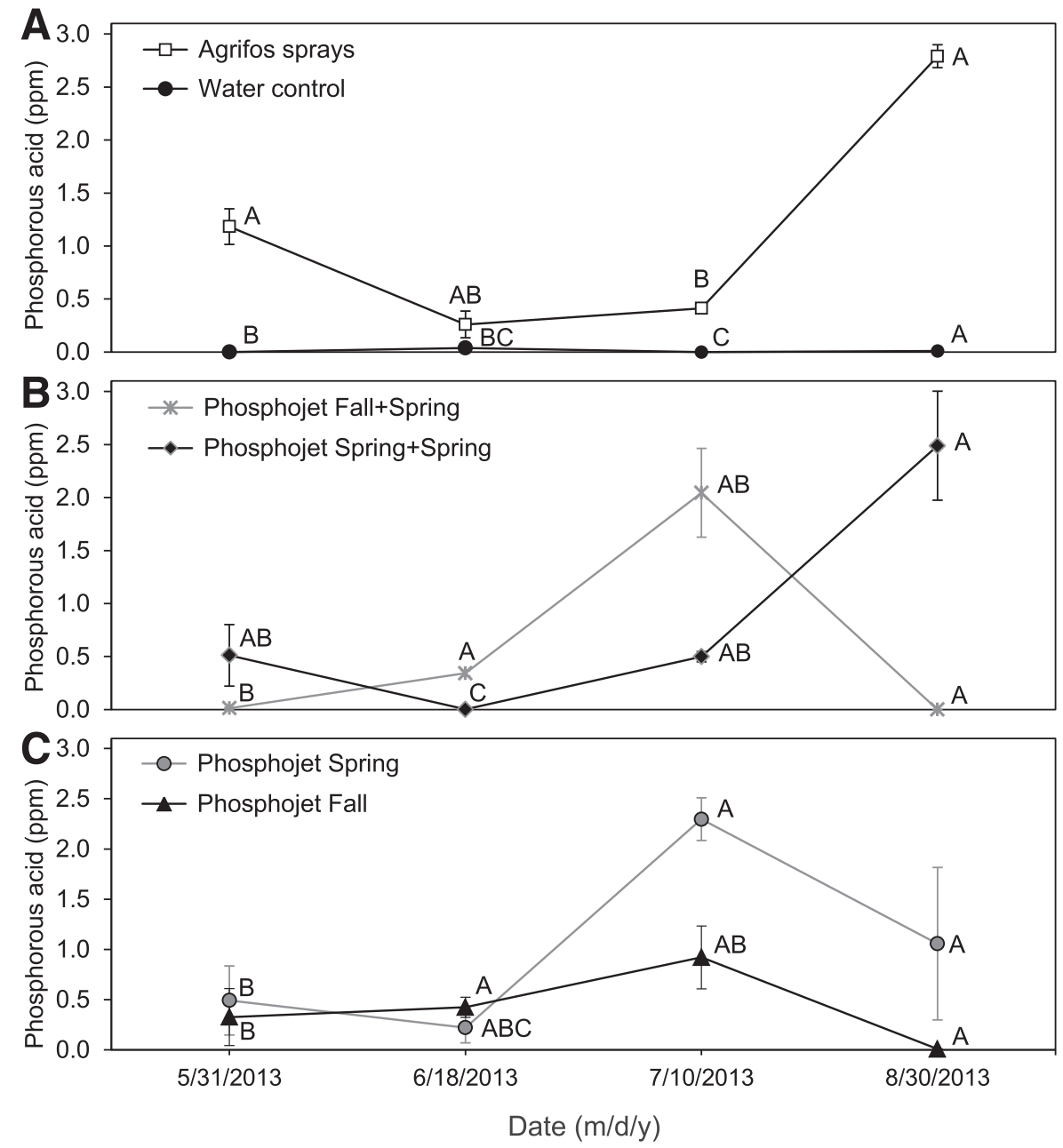

Fig. 5. Fruit residue profiles of sprayed (A) and trunk-injected potassium phosphites (B, C) in 'Mac Spur' apple trees. Fall/Spring - injection time. Residue means within one date followed by different letters are significantly different between the treatments and across the graphs ( $t$ tests, $\alpha=0.05)$. Error bars represent standard error of the mean (SEM). 
injection to limit adverse effects on plant tissues. Both will secure rapid and desired effect on plant pathogen or insect pest (Doccola and Wild 2012; Kondo 1978; Montecchio 2013).

The residue profiles from experiment 3 show that at some time points, fall injection provided significantly higher accumulation of injected cyprodinil and difenoconazole in leaves and fruit when compared with other injections of this combination. This was probably driven by substantial time for compound translocation after injection. Even though the higher accumulation should provide better control of scab, the residue levels of injected cyprodinil and difenoconazole seem to be far below the toxic limits for $V$. inaequalis, which could yield expected control differences. Hence, fall injection improved cyprodinil and difenoconazole accumulation insufficiently to improve scab control. It is unexpected that on shoot leaves, one spring injection of cyprodinil and difenoconazole provided statistically better scab control than one fall injection, opposite to the aforementioned residue profiles. It is possible that with time, metabolic changes of oxidation, hydrolysis, and conjugation affected activity of more abundant cyprodinil and difenoconazole after fall injection through conversion into inactive metabolites (Lindquist 1965). Nevertheless, these metabolites were probably detected in our residue analysis.

In experiment 2, the peaks in propiconazole residue profiles did not align with the best scab control on leaves. The residues indicate that accumulation of propiconazole followed gradual spur and shoot leaf development. Low propiconazole concentrations, detected before 23 May, affected apple scab, probably because the leaf mass was small in volume thus allowing significant impact on disease. With the increase of transpiring leaf area on spurs and shoots, more propiconazole residues accumulated in leaves and kept affecting the pathogen. However, scab reduction was lower in comparison with phosphites, probably because the accumulated propiconazole residues were insufficient for better effect. Also, scab control could have been weakened by known resistance of $V$. inaequalis to triazoles (Köller et al. 1997), residue dilution with new green growth, and plant metabolic processes that inactivate molecule activity (Campana et al. 1979; Lamoureux and Frear 1979; Lindquist 1965).

In experiment 3 , residue peaks after injection of phosphites, cyprodinil, and difenoconazole occurred before disease was rated on leaves and fruit. Residue profiles show short-lasting but high concentration peaks of phosphites and somewhat longer-lasting but lower concentration peaks of cyprodinil and difenoconazole during accumulation. These temporary maximums in residue profiles did not match well in magnitude with long-lasting and high scab infection periods. The efficiency in scab control was likely weakened by this discrepancy. In contrast, cyprodinil and difenoconazole sprays provided significantly higher and much more temporally stable residue coverage on leaves, which resulted in better scab control. Interestingly, phosphite sprays were similar in residue profiles with phosphite injection.

Overall, the residue profiles demonstrate that translocation and accumulation of injected compounds in the canopy is a time-consuming process strongly shaped by tree physiology and tissue resistance points (Coomes 2006; McCulloh et al. 2003). This is opposite to the immediate coating of the canopy by foliar spray applications. Furthermore, even though phosphite injection dose per tree was 1.6 to 2 times higher than in phosphite sprays, the fact that only two phosphite injections provided better control of fruit and spur leaf scab than nine phosphite sprays indicated better persistence of injected phosphites. Hence, trunk injection is a superior method for delivering phosphites because it enhances their activity and extends it to two growing seasons. This could offer opportunity for cost reduction in apple scab control and lower the risks in development of pathogen resistance (Deliopoulos et al. 2010). However, future research should elucidate any potential side effects of repeated trunk injection on tree physiology and longevity.

The compound residues in apple fruit declined after injections and sprays. This was probably driven by metabolic and environmental degradation of a.i.'s, rainfastness, and in case of injection, by reduction in fruit transpiration due to natural dysfunction of fruit xylem during ripening (Dražeta et al. 2004). Residue concentrations in fruit after injection were far below the United States, Codex, and EU
MRL-s of 1, 0.8, and $0.5 \mathrm{ppm}$ for difenoconazole and 1.7, 2, and 1 ppm for cyprodinil, respectively. Phosphites are exempt from food tolerances in the United States (US EPA 2006). Therefore, since the vast majority of residues accumulate in foliage versus fruit, trunk injection resulted in a discriminatory distribution of compounds within the apple tree.

In summary, we show that two to three trunk injections of systemic compounds could be a valuable alternative to spray applications in apple scab control. The effects of trunk-injected phosphites extended to two growing seasons and phosphites served as a better model for optimizing apple scab control due to their good mobility in xylem. Residues of injected compounds in apple fruit were far below the current food tolerances. Specific physiologies of different apple tree organs governed compound accumulation in concert with their chemical properties. Our findings warrant further investigation of trunk injection as the most favorable environmental method in protection of fruit trees according to the principles of precision agriculture.

\section{Acknowledgments}

This work was funded by the Michigan Apple Research Committee for the project "Trunk Injection of Fungicides and Bio-pesticides for Apple Scab Control" and the IR-4 Project "Enhancing Performance of Phosphorous Acid Salts for Apple Scab Management through Trunk Injection Delivery," both to JCW. Appreciation to Joseph Doccola, director of Research and Development at Arborjet Inc. Woburn, MA, for donating the injection equipment and chemicals. Thank you to research technicians Laura Lamb and Christopher Meredith for helping in disease rating, injections, sample collection, and processing. We acknowledge Drs Annemiek Schilder, Brad Day, Jim Miller, and Randolph Beaudry for using the equipment of their laboratories at MSU. We thank staff of the MSU TNRC for maintenance of the field plots.

\section{Literature Cited}

Aćimović, S. G., Mcghee, G. C., Sundin, G. W., and Wise, J. C. 2015a. Evaluation of trunk-injected bactericides and prohexadione-calcium for environmentally friendly control of fire blight (Erwinia amylovora) in apples. Pages 129-134 in: Proceedings of the 7th Congress on Plant Protection. D. Marčić, M Glavendekić, and P. Nicot, eds. Plant Protection Society of Serbia, IOBCEPRS and IOBC-WPRS, Belgrade, Serbia

Aćimović, S. G., VanWoerkom, A. H., Reeb, P. D., Vandervoort, C., Garavaglia, T., Cregg, B. M., and Wise, J. C. 2014. Spatial and temporal distribution of trunk-injected imidacloprid in apple tree canopies. Pest Manag. Sci. 70: $1751-1760$.

Aćimović, S. G., Zeng, Q., Mcghee, G. C., Sundin, G. W., and Wise, J. C. 2015 b. Control of fire blight (Erwinia amylovora) on apple trees with trunk-injected plant resistance inducers and antibiotics and assessment of induction of pathogenesis-related protein genes. Front. Plant Sci. 6:16.

Ahmed, M. A., Abdelbagi, A. O., and Elshafie, H. A. 2010. Trunk injection with neonictoniods insecticides to control the green pit scale insect (Palmapsis phoenicis Ramachandra Rao) (Homoptera: Asterolecaniidae) infesting date palm in northern Sudan. Pages 937-955 in: IV International Date Palm Conference. A. Zaid and G. A. Alhadrami, eds. Acta Horticulturae (ISHS) 882, Abu Dhabi, United Arab Emirates.

Balaž, J., Aćimović, S., Aleksić, G., Bodroža, M., and Cvetković, B. 2010. Evaluation of possibilities of Venturia inaequlis control by ecologically acceptable products. Pestic. Fitomedicina. 25:335-342.

Beckerman, J. L., Sundin, G. W., and Rosenberger, D. A. 2015. Do some IPM concepts contribute to the development of fungicide resistance? Lessons learned from the apple scab pathosystem in the United States. Pest Manag. Sci. 71:331-342.

Blanke, M. M., and Lenz, F. 1989. Fruit photosynthesis. Plant Cell Environ. 12: 31-46.

Byrne, F. J., Krieger, R. I., Doccola, J., and Morse, J. G. 2014. Seasonal timing of neonicotinoid and organophosphate trunk injections to optimize the management of avocado thrips in California avocado groves. Crop Prot. 57:20-26.

Campana, R. J., Kielbaso, J. J., Davidson, H., Hart, J., Jones, A., and Kennedy, M. K. 1979. Characteristics of successful systemic chemicals. Pages 19-34 in: Proceedings of the Symposium on Systemic Chemical Treatments in Tree Culture. J. J. Kielbaso, ed. Michigan State University, East Lansing, MI.

Coomes, D. A. 2006. Challenges to the generality of WBE theory. Trends Ecol. Evol. 21:593-596.

Creemers, P., and Van Laer, S. 2006. Key strategies for reduction of the dependence on fungicides in integrated fruit production. Phytopathology 39 19-29.

Dal Maso, E., Cocking, J., and Montecchio, L. 2014. Efficacy tests on commercial fungicides against ash dieback in vitro and by trunk injection. Urban For. Urban Green. 13:697-703.

Deliopoulos, T., Kettlewell, P. S., and Hare, M. C. 2010. Fungal disease suppression by inorganic salts: A review. Crop Prot. 29:1059-1075. 
Doccola, J. J., Hascher, W., Aiken, J. J., and Wild, P. M. 2012. Treatment strategies using imidacloprid in hemlock woolly adelgid (Adelges tsugae Annand) infested eastern hemlock (Tsuga canadensis Carrière). Trees. Arboric. Urban For. 38:41-49.

Doccola, J. J., and Wild, P. M. 2012. Tree injection as an alternative method of insecticide application. Pages 61-78 in: Insecticides - Basic and Other Applications. S. Soloneski and M. Larramendy, eds. InTech, Croatia.

Dragoni, D., Lakso, A. N., and Piccioni, R. M. 2005. Transpiration of apple trees in a humid climate using heat pulse sap flow gauges calibrated with whole-canopy gas exchange chambers. Agric. For. Meteorol. 130:85-94.

Dražeta, L., Lang, A., Hall, A. J., Volz, R. K., and Jameson, P. E. 2004. Causes and effects of changes in xylem functionality in apple fruit. Ann. Bot. (Lond.) 93: 275

Düker, A., and Kubiak, R. 2011. Stem injection of prohexadione carboxylic acid to protect blossoms of apple trees from fire blight infection (Erwinia amylovora). J. Plant Dis. Prot. 118:156-160.

Ecobichon, D. J. 1999. Occupational hazards of pesticide exposure: sampling, monitoring, and measuring, 1st Ed. CRC Press, Boca Raton, FL.

EFSA. 2012. Conclusion on the peer review of the pesticide risk assessment of the active substance potassium phosphonates, European Food Safety Authority. EFSA J. 10:1-43.

Ehler, L. E. 2006. Integrated pest management (IPM): definition, historical development and implementation, and the other IPM. Pest Manag. Sci. 62: 787-789.

Ehler, L. E., and Bottrell, D. G. 2000. The Illusion of Integrated Pest Management. Issues Sci. Technol. Online: http://issues.org/16-3/ehler/

Ehret, G. R., Sundin, G. W., McGhee, G. C., and Lesniak, K. E. 2010. Control of apple scab with fungicides applied on a 9-day protective schedule. PDMR Report No. 5:PF028.

Epstein, L. 2014. Fifty years since Silent Spring. Annu. Rev. Phytopathol. 52: $377-402$.

FAO and WHO. 2010. Pesticide residues in food 2010, Joint FAO/WHO Meeting on Pesticide Residues. Online: http://www.fao.org/docrep/013/i1949e/i1949e.pdf

Gadoury, D. M., Seem, R. C., MacHardy, W. E., Wilcox, W. F., Rosenberger, D. A., and Stensvand, A. 2004. A comparison of methods used to estimate the maturity and release of ascospores of Venturia inaequalis. Plant Dis. 88:869-874.

Hamilton, D., Ambrus, Á., Dieterle, R., Felsot, A., Harris, C., Petersen, B., Racke, K., Wong, S.-S., Gonzalez, R., Tanaka, K., Earl, M., Roberts, G., and Bhula, R. 2004. Pesticide residues in food-acute dietary exposure. Pest Manag. Sci. 60: 311-339.

Heaton, J. B., and Dullahide, S. R. 1990. Efficacy of phosphonic acid in other host pathogen systems. Australas. Plant Pathol. 19:133-134.

Herner, A. E., and Acock, B. 2003. USDA-ARS Pesticide Properties Database. Encyclopedia of Agrochemicals. John Wiley \& Sons, Inc., Hoboken, NJ.

Holb, I. J., Heijne, B., Withagen, J. C. M., Gáll, J. M., and Jeger, M. J. 2005. Analysis of summer epidemic progress of apple scab at different apple production systems in the Netherlands and Hungary. Phytopathology 95:1001-1020.

Jacobsen, B. J. 1997. Role of plant pathology in integrated pest management. Annu. Rev. Phytopathol. 35:373-391.

Jamar, L. 2011. Innovative strategies for the control of apple scab (Venturia inaequalis [Cke.] Wint.) in organic apple production. Ph.D. Thesis, Université de Liège, Gembloux, Belgium.

Jamar, L., Cavelier, M., and Lateur, M. 2010. Primary scab control using a "duringinfection" spray timing and the effect on fruit quality and yield in organic apple production. Biotechnol. Agron. Soc. Environ. 14:423-439.

Kogan, M. 1998. Integrated pest management: Historical perspectives and contemporary developments. Annu. Rev. Entomol. 43:243-270.

Köller, W., Wilcox, W. F., Barnard, J., Jones, A. L., and Braun, P. G. 1997. Detection and quantification of resistance of Venturia inaequalis populations to sterol demethylation inhibitors. Phytopathology 87:184-190.

Kondo, E. S. 1978. Scope and limitations of carbendazim $\mathrm{H}_{2} \mathrm{PO}_{4}$ injections in Dutch elm disease control. J. Arboric. 4:80-86.

Lamoureux, G. L., and Frear, D. S. 1979. Pesticide metabolism in higher plants: In vitro enzyme studies. Pages 77-128 in: Xenobiotic Metabolism: In Vitro Methods. G. D. Paulson, D. S. Frear, and E. P. Marks, eds. ACS Symposium Series American Chemical Society, Washington, DC.

Lindquist, D. A. 1965. Systemic pesticides in woody plants: Metabolism. Bull. ESA. 11:195-198

Malusà, E., and Tosi, L. 2005. Phosphorous acid residues in apples after foliar fertilization: Results of field trials. Food Addit. Contam. 22:541-548.

McCulloh, K. A., Sperry, J. S., and Adler, F. R. 2003. Water transport in plants obeys Murray's law. Nature 421:939-942.

Mensink, B. 2008. Environmental risk limits for difenoconazole. National Institute for Public Health and the Environment, Bilthoven, Netherlands. Online: http:// www.rivm.nl/bibliotheek/rapporten/601716005.pdf

Montecchio, L. 2013. A Venturi effect can help cure our trees. J. Vis. Exp. 80: $10.3791 / 51199$.
Mota-Sanchez, D., Cregg, B. M., McCullough, D. G., Poland, T. M., and Hollingworth, R. M. 2009. Distribution of trunk-injected 14C-imidacloprid in ash trees and effects on emerald ash borer (Coleoptera: Buprestidae) adults. Crop Prot. 28:655-661

Ohlendorf, B. L. P. 1999. Integrated pest control management for apples and pears. 2nd ed. University of California, Statewide Integrated Pest Management Project 3340, Division of Agriculture and Nature Resources, Davis, CA

Percival, G. C. 2010. Effect of systemic inducing resistance and biostimulant materials on apple scab using a detached leaf bioassay. Arboric. Urban For. 36:41-46.

Percival, G. C., and Boyle, S. 2005. Evaluation of microcapsule trunk injections for the control of apple scab and powdery mildew. Ann. Appl. Biol. 147:119-127.

Percival, G. C., Noviss, K., and Haynes, I. 2009. Field evaluation of systemic inducing resistance chemicals at different growth stages for the control of apple (Venturia inaequalis) and pear (Venturia pirina) scab. Crop Prot. 28: 629-633

Pimentel, D. 2005. Environmental and Economic Costs of the Application of Pesticides Primarily in the United States. Environ. Dev. Sustain. 7:229-252.

Pimentel, D., and Burgess, M. 2014. Environmental and economic benefits of reducing pesticide use. Pages 127-139 in: Integrated Pest Management. D. Pimentel and R. Peshin, eds. Springer, Dordrecht, Netherlands.

Pimentel, D., and Levitan, L. 1986. Pesticides: Amounts applied and amounts reaching pests. Bioscience 36:86-91.

PPDB. 2013. Pesticide Properties DataBase - difenoconazole (Ref: CGA 169374) Pestic. Prop. DataBase. Online: http://sitem.herts.ac.uk/aeru/ppdb/en/Reports/ 230.htm

Rawn, D. F. K., Quade, S. C., Shields, J. B., Conca, G., Sun, W.-F., Lacroix, G. M. A., Smith, M., Fouquet, A., and Bélanger, A. 2007. Variability in captan residues in apples from a Canadian orchard. Food Addit. Contam. 24:149-155.

Reganold, J. P., Glover, J. D., Andrews, P. K., and Hinman, H. R. 2001. Sustainability of three apple production systems. Nature 410:926-930.

Serafini, M. P. 2003. Cyprodinil new product registration and registration application withdrawal 2/03. PMEP - Pesticide Management Education Program, Cornell University. Online: http://pmep.cce.cornell.edu/profiles/fung-nemat/ aceticacid-etridiazole/cyprodinil/cyprodinil_reg_203.html

Smillie, R., Grant, B. R., and Guest, D. 1989. The mode of action of phosphite: evidence for both direct and indirect modes of action on three Phytophthora spp. in plants. Phytopathology 79:921-926.

Smith, I. M., Dunez, J., Phillips, D. H., Lelliott, R. A., and Archer, S. A., eds. 1988 European handbook of plant diseases. Blackwell Scientific Publications, Oxford.

Smitley, D. R., Doccola, J. J., and Cox, D. L. 2010. Multiple-year protection of ash trees from emerald ash borer with a single trunk injection of emamectin benzoate, and single-year protection with an imidacloprid basal drench. J. Arboric. 36:206

Spitko, R. 2008. Efficacy of microinjected Apogee and ArborFos against fire blight disease incidence and shoot growth of apple. J.J. Mauget Co., Arcadia, CA. Online: http://mauget.com/wp-content/uploads/2015/08/Fire_Blight.pdf

Steiner, P. W. 1969. The distribution of spray material between target and nontarget areas of a mature apple orchard by airblast equipment. M.S. thesis, Cornell University, Ithaca, NY.

Stensvand, A., Eikemo, H., Gadoury, D. M., and Seem, R. C. 2005. Use of a rainfall frequency threshold to adjust a degree-day model of ascospore maturity of Venturia inaequalis. Plant Dis. 89:198-202.

Sutton, T. B. 1996. Changing options for the control of deciduous fruit tree diseases. Annu. Rev. Phytopathol. 34:527-547.

Tanis, S. R., Cregg, B. M., Mota-Sanchez, D., McCullough, D. G., and Poland, T. M. 2012. Spatial and temporal distribution of trunk-injected 14C-imidacloprid in Fraxinus trees. Pest Manag. Sci. 68:529-536.

Tomlin, C. D. S. 2011. The Pesticide Manual: A World Compendium. British Crop Protection Council, Surrey, UK.

US EPA. 2006. Phosphorous acid and its ammonium, sodium, and potassium salts (076002) Mono- and di-potassium salts of phosphorous acid (076416) Fact Sheet. Office of Pesticide Programs, Environmental Protection Agency, Washington, DC. Online: https://www3.epa.gov/pesticides/chem_search/reg_actions/ registration/fs_G-133_04-April-00.pdf

VanWoerkom, A. H., Aćimović, S. G., Sundin, G. W., Cregg, B. M., MotaSanchez, D., Vandervoort, C., and Wise, J. C. 2014. Trunk injection: An alternative technique for pesticide delivery in apples. Crop Prot. 65:173-185.

Walters, D. R., and Bingham, I. J. 2007. Influence of nutrition on disease development caused by fungal pathogens: implications for plant disease control. Ann. Appl. Biol. 151:307-324.

Wise, J. C., VanWoerkom, A. H., Aćimović, S. G., Sundin, G. W., and Cregg, B. M. 2014. Trunk injection: A discriminating delivering system for horticulture crop IPM. J. Entomol. Ornithol. Herpetol. 3:126.

Zhang, M., Powell, C. A., Zhou, L., He, Z., Stover, E., and Duan, Y. 2011. Chemical compounds effective against the citrus huanglongbing bacterium "Candidatus Liberibacter asiaticus" in planta. Phytopathology 101:1097-1103. 